\title{
Activation of a pro-enzyme by a stoichiometric reaction with another protein
}

Citation for published version (APA):

Hemker, H. C., Bas, B. M., \& Muller, A. D. (1975). Activation of a pro-enzyme by a stoichiometric reaction with another protein: The reaction between prothrombin and staphylocoagulase. Biochimica et Biophysica Acta (BBA) - Protein Structure, 379(1), 180-188. https://doi.org/10.1016/0005-2795(75)90020-3

Document status and date:

Published: 30/01/1975

DOI:

10.1016/0005-2795(75)90020-3

Document Version:

Other version

\section{Please check the document version of this publication:}

- A submitted manuscript is the version of the article upon submission and before peer-review. There can be important differences between the submitted version and the official published version of record.

People interested in the research are advised to contact the author for the final version of the publication, or visit the DOI to the publisher's website.

- The final author version and the galley proof are versions of the publication after peer review.

- The final published version features the final layout of the paper including the volume, issue and page numbers.

Link to publication

\footnotetext{
General rights rights.

- You may freely distribute the URL identifying the publication in the public portal. please follow below link for the End User Agreement:

www.umlib.nl/taverne-license

Take down policy

If you believe that this document breaches copyright please contact us at:

repository@maastrichtuniversity.nl

providing details and we will investigate your claim.
}

Copyright and moral rights for the publications made accessible in the public portal are retained by the authors and/or other copyright owners and it is a condition of accessing publications that users recognise and abide by the legal requirements associated with these

- Users may download and print one copy of any publication from the public portal for the purpose of private study or research.

- You may not further distribute the material or use it for any profit-making activity or commercial gain

If the publication is distributed under the terms of Article $25 \mathrm{fa}$ of the Dutch Copyright Act, indicated by the "Taverne" license above, 
Reprinted from

Biochimica et Biophysica Acta, 379 (1975) 180-188

(C) Elsevier Scientific Publishing Company, Amsterdam - Printed in The Netherlands

BBA 36914

\section{ACTIVATION OF A PRO-ENZYME BY A STOICHIOMETRIC REACTION WITH ANOTHER PROTEIN}

THE REACTION BETWEEN PROTHROMBIN AND STAPHYLOCOAGULASE

H. C. HEMKER* ${ }^{*}$ B. M. BAS and A. D. MULLER

Laboratory of Cardiovascular and Blood Coagulation Biochemistry, Department of Internal Medicine, University Medical Centre, Leiden (The Netherlands)

(Received July 2nd, 1974)

\section{SUMMARY}

The reaction between prothrombin and staphylocoagulase was investigated and the following conclusions were drawn:

(a) Optimal amounts of the active reaction product (coagulase-thrombin) are found when equimolar amounts of prothrombin and staphylocoagulase are added together.

(b) The molecular weight of coagulase-thrombin equals the sum of the molecular weights of staphylocoagulase and prothrombin when estimated both by gelfiltration and by sodium dodecylsulphate-polyacrylamide gel electrophoresis.

(c) The amino acid composition of coagulase-thrombin cannot be distinguished from the sum of the amino acid compositions of prothrombin and staphylocoagulase.

(d) In a preparation of coagulase-thrombin the $\mathrm{N}$-terminal amino acids are those of prothrombin (alanin) and staphylocoagulase (aspartic acid).

(e) An antibody against coagulase-thrombin precipitates prothrombin and staphylocoagulase but not thrombin.

(f) We put forward the hypothesis that the thrombin activity in coagulasethrombin is the result of a stoichiometric reaction between one molecule of prothrombin and one molecule of staphylocoagulase, and limited proteolysis does not play a role in this mechanism.

\section{INTRODUCTION}

Prothrombin is a single-chain protein (mol. wt. $\approx 73000$ ) which is subjected in the course of the blood coagulation process to limited proteolysis and so yields one molecule of thrombin [1-4]. Thrombin is a two-chain serine protease (mol. wt. 39 000), the $\beta$-chain of which shows extensive homologies with trypsin, chymotrypsin $A$ and

* To whom all correspondence should be addressed at the Medical Faculty Maastricht, Tongersestraat 53, Maastricht, The Netherlands. 
B, and elastase [5]. Staphylocoagulase is a protein secreted by certain strains of Staphylococcus aureus. It produces a thrombin-like activity in prothrombin. This activity we call coagulase-thrombin $[6,7]$.

Coagulase-thrombin can be distinguished from normal thrombin in that it is not inhibited by heparin and soybean trypsin inhibitor [8]; also, its chromatographic behavior on DEAE-cellulose is different [9].

There are indications that coagulase-thrombin arises not from prothrombin by a proteolytic action of staphylocoagulase, but rather by the formation of a stoichiometric product from one molecule of prothrombin and one molecule of staphylocoagulase. Soulier found that purified coagulase-thrombin is inhibited by antibodies against prothrombin as well as by antibodies against staphylocoagulase [9]. Muller and Hemker showed in a preliminary report that the molecular weight of coagulasethrombin equals the sum of the molecular weights of staphylocoagulase and prothrombin [10].

The purpose of this study was to determine whether staphylocoagulase induces activity in prothrombin by limited proteolysis or by a stoichiometric reaction.

\section{MATERIALS AND METHODS}

Unless stated otherwise, chemicals were obtained from Merck A.G. and were of analytic grade. Human prothrombin was prepared according to Devilee et al. [11]. Staphylocoagulase was prepared as described by Bas et al. [21]. Bovine factor V was prepared according to Barton [13], bovine factor X was prepared according to Jackson et al. [14]. The conversion (by the physiological mechanism, i.e., factor $\mathrm{X}_{\mathrm{a}}$, factor $\mathrm{V}$, and phospholipid) of prothrombin into thrombin and the purification of the latter were carried out according to Owen et al. [3]. When necessary, this preparation will be called normal thrombin to distinguish it from coagulase-thrombin.

The esterase activity was followed in a $\mathrm{pH}$ stat (Radiometer) at $37^{\circ} \mathrm{C}$ under a flux of $\mathrm{N}_{2}$. The reaction mixture consisted of $4.8 \mathrm{ml} 5 \mathrm{mM}$ Tos-Arg-OMe (Sigma) in $0.1 \mathrm{M} \mathrm{NaCl}$ adjusted to $\mathrm{pH} 7.35,0.2 \mathrm{ml}$ of the sample was added and the titration carried out with $2 \mathrm{mM} \mathrm{NaOH}$ in $0.1 \mathrm{M} \mathrm{NaCl}$. Prothrombin determinations were carried out as described in ref. 15. Staphylocoagulase was determined according to Soulier [9]. Coagulation times with coagulase-thrombin were determined by adding a $0.1-\mathrm{ml}$ sample to $0.1 \mathrm{ml}$ of a $4 \mathrm{mg} / \mathrm{ml}$ fibrinogen solution (bovine fibrinogen, Behring Werke A.G.) and assessing the moment of coagulation manually with a $5 \times$ $30 \mathrm{~mm}$ steel hook.

Gel filtration, sodium dodecylsulphate-polyacrylamide gel electrophoresis, amino acid analysis, and determinations of $\mathrm{N}$-terminal amino acids were carried out as described in ref. 12.

\section{EXPERIMENTS}

\section{Generation of activity}

The addition of purified staphylocoagulase to purified prothrombin leads to the generation of a product that has both Tos-Arg-OMe-esterase activity and the ability to clot fibrinogen. Figs 1 and 2 show that the amount of esterase activity that evolves is a function of both the quantity of staphylocoagulase and the quantity of prothrom- 


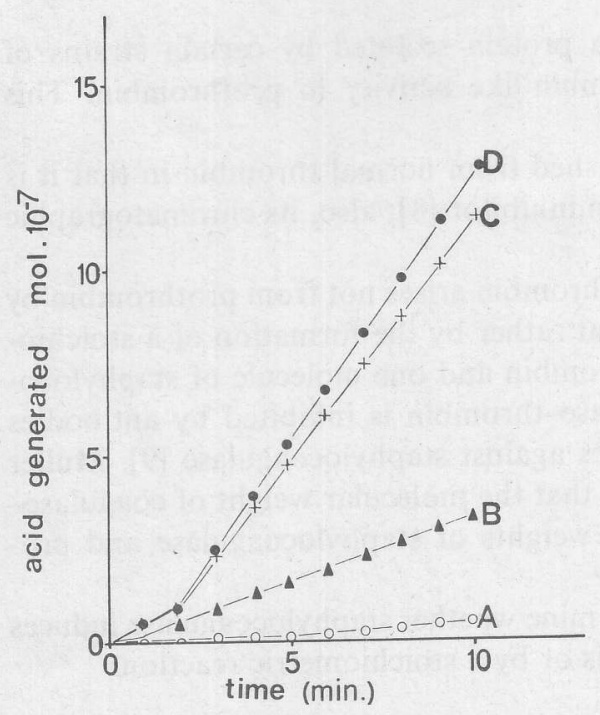

Fig. 1. Tos-Arg-OMe hydrolysis by coagulase-thrombin. The amount of ester hydrolysed is given as a function of time. Reaction mixture $\mathrm{C}: 0.10 \mathrm{ml}$ staphylocoagulase $(2 \mathrm{mg} / \mathrm{ml})$ and $\mathrm{d}^{1} .10 \mathrm{ml}$ prothrombin $(10 \mathrm{mg} / \mathrm{ml}) ; 4.8 \mathrm{ml}$ Tos-Arg-OMe $5 \mathrm{mM}$ (pH 7.35) in $0.1 \mathrm{M} \mathrm{NaCl}$. In the other mixtures prothrombin or staphylocoagulase solutions were (partially) replaced by $0.1 \mathrm{M} \mathrm{NaCl}$ so as to obtain the concentrations indicated below. No observable esterase activity developed when no prothrombin was added. Final cocnentrations: A: staphylocoagulase $0 \mu \mathrm{g} / \mathrm{ml}$; prothrombin $200 \mu \mathrm{g} / \mathrm{ml}$; B: staphylocoagulase $10 \mu \mathrm{g} / \mathrm{ml}$; prothrombin $200 \mu \mathrm{g} / \mathrm{ml}$; C: staphylocoagulase $40 \mu \mathrm{g} / \mathrm{ml}$; prothrombin 200 $\mu \mathrm{g} / \mathrm{ml}$; D: staphylocoagulase $40 \mu \mathrm{g} / \mathrm{ml}$; prothrombin $50 \mu \mathrm{g} / \mathrm{ml}$.

bin present. After two minutes the activity in the mixture is maximal and stable. For each concentration of staphylocoagulase there is a lowest concentration of prothrombin that gives maximal activity. Any further increase in prothrombin concentration will not raise the esterase activity further. The same phenomenon can be observed with

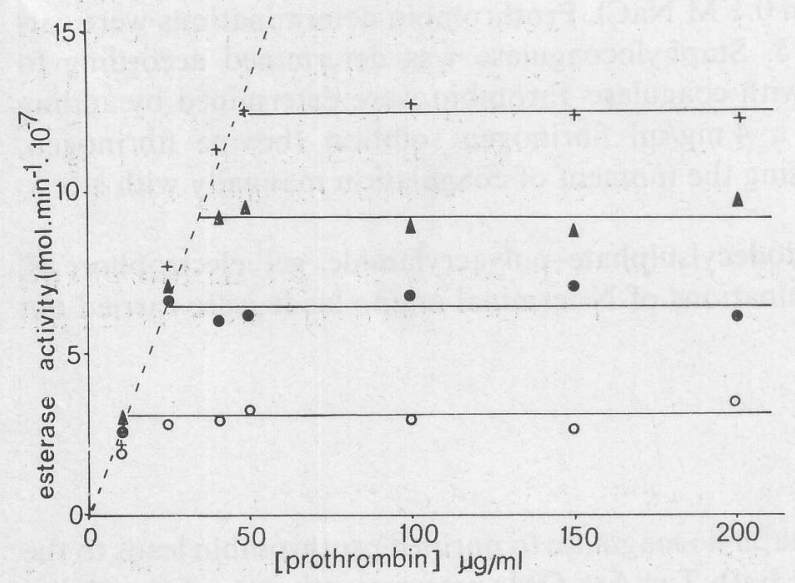

Fig. 2. Esterase activity in mixtures of prothrombin and staphylocoagulase. The esterase activity was determined with varying amounts of prothrombin as indicated on the abscissa and the following amounts of staphylocoagulase: $\mathrm{O}: 10 \mu \mathrm{g} / \mathrm{ml} ; 0: 20 \mu \mathrm{g} / \mathrm{ml} ; \boldsymbol{\Delta}: 30 \mu \mathrm{g} / \mathrm{ml} ;+: 40 \mu \mathrm{g} / \mathrm{ml}$. 


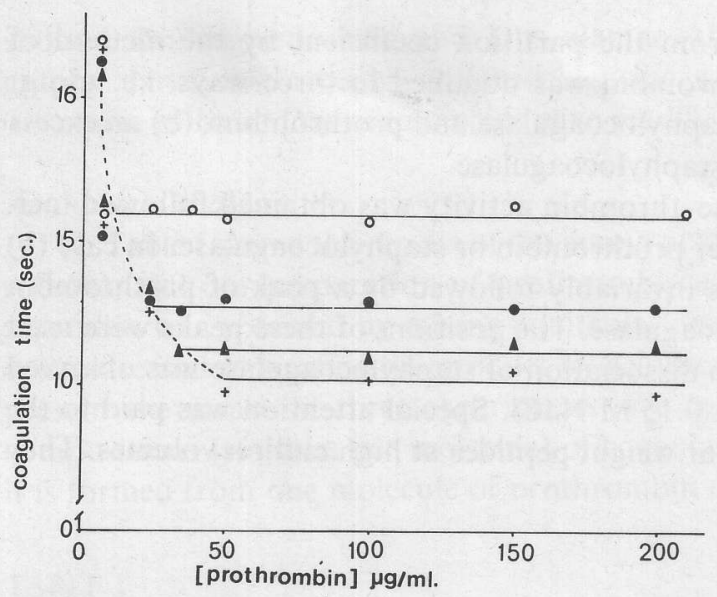

Fig. 3. Clotting activity in mixtures of prothrombin and staphylocoagulase. The coagulation activity was determined with varying amounts of prothrombin, as indicated on the abcissa, and the following amounts of staphylocoagulase: $0: 10 \mu \mathrm{g} / \mathrm{ml} ; \bullet: 20 \mu \mathrm{g} / \mathrm{ml} ; \mathbf{\Delta}: 30 \mu \mathrm{g} / \mathrm{ml} ;+: 40 \mu \mathrm{g} / \mathrm{ml}$.

the coagulation times: for each concentration of staphylocoagulase there is a lowest concentration of prothrombin that will cause maximal coagulation activity, i.e. a minimal coagulation time (Fig. 3).

This type of experiment indicates the minimal concentration of prothrombin that will just cause optimal activity in a given amount of staphylocoagulase (and vice versa). The pairs of concentrations thus found are plotted in Fig. 4. Optimal esterase activity coincided with optimal coagulation activity.

\section{Estimation of the molecular weight}

Preparations of prothrombin, staphylocoagulase, coagulase-thrombin and normal thrombin were subjected to gel filtration on Biogel P-100 and P-150. The

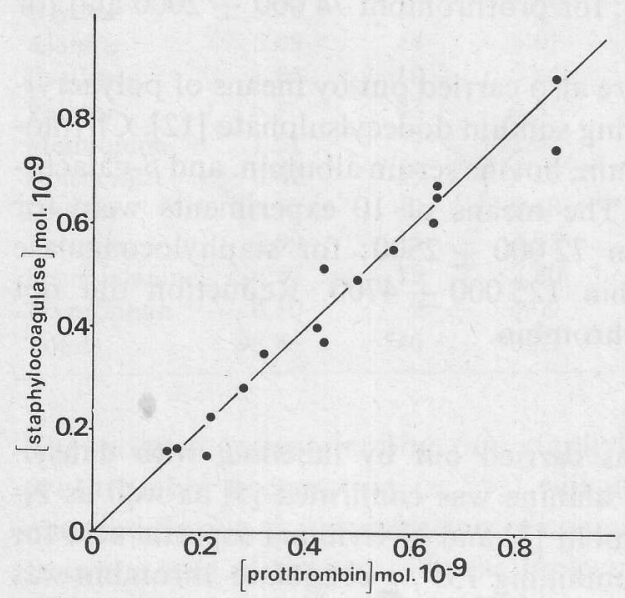

Fig. 4. Ratio of prothrombin to staphylocoagulase at optimal activity. Molar concentrations calculated for a molecular weight of prothrombin of 73000 and staphylocoagulase 61000 . 
molecular weight was determined from the partition coefficient by the method of Andrews [16] (Fig. 5). Coagulase-thrombin was obtained in three ways, i.e. using: (a) roughly equimolar amounts of staphylocoagulase and prothrombin; (b) an excess of prothrombin, or (c) an excess of staphylocoagulase.

In case (a) a peak of coagulase-thrombin activity was obtained followed incidentally by a very small peak of either prothrombin or staphylocoagulase. In case (b) the peak of coagulase-thrombin was invariably followed by a peak of prothrombin and in case (c) by a peak of staphylocoagulase. The positions of these peaks were used to calculate partition coefficients. No dissociation of staphylocoagulase was observed in the $\mathrm{pH}$ range $6-8$ with or without $0.15 \mathrm{M} \mathrm{NaCl}$. Special attention was paid to the possible occurrence of small molecular weight peptides at high elution volumes. They could not be found.

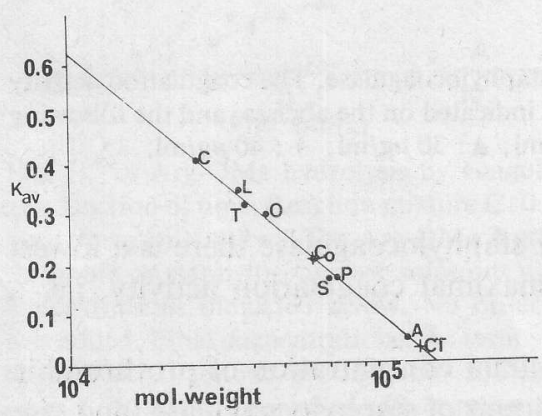

Fig. 5. Estimation of the molecular weight of staphylocoagulase, prothrombin, thrombin and coagulase-thrombin by gel filtration. Gel filtration was carried out at pH 7.35 in $0.05 \mathrm{M} \mathrm{Tris- \textrm {HCl }}$ buffer. The $\log$ of the molecular weight is plotted against $K_{\mathrm{av}}$. A: alcohol dehydrogenase $(n=30)$; C: chymotrypsinogen $(n=30)$; CT: coagulase-thrombin $(n=20)$; Co: staphylocoagulase $(n=10)$; L: lactate dehydrogenase $(n=30) ; \mathrm{O}$ : ovalbumin $(n=30) ; \mathbf{P}$ : prothrombin $(n=10)$; S: bovine serum albumin $(n=30)$; T: thrombin $(n=5)$. $(n=$ number of experiments).

For staphylocoagulase, a molecular weight of $62000 \pm 3000$ (S.E.) was found; for thrombin this value was $37000 \pm 1500$; for prothrombin $74000 \pm 2000$ and for coagulase-thrombin $135000 \pm 5400$.

Molecular weight determinations were also carried out by means of polyacrylamide-gel electrophoresis in buffers containing sodium dodecylsulphate [12]. Chymotrypsinogen, lactate dehydrogenase, ovalbumin, bovine serum albumin. and $\beta$-galactosidase were used as reference molecules. The means of 10 experiments were for thrombin $39000 \pm 1600$; for prothrombin $72000 \pm 2500$; for staphylocoagulase $60000 \pm 2300$, and for coagulase-thrombin $125000 \pm 4700$. Reduction did not change the molecular weight of coagulase-thrombin.

\section{$N$-terminal amino acid analysis}

$\mathrm{N}$-terminal amino acid analysis was carried out by labelling with dansylchloride. For prothrombin, an N-terminal alanine was confirmed [5] as well as Nterminal threonine and isoleucine for thrombin [5] and $\mathrm{N}$-terminal aspartic acid for staphylocoagulase [12]. A $0.2-\mathrm{ml}$ aliquot containing $135 \mu \mathrm{g}$ coagulase-thrombin was dansylated and hydrolyzed as in ref. 12. The maximal yield of dansylated $\mathrm{N}$-terminal amino acids was $\approx 1.0$ nmole. Chromatography on polyamide thin layers $(5 \times 5 \mathrm{~cm})$ 
showed Dns-aspartic acid and Dns-alanine, this was confirmed by co-chromatography. No Dns-threonine or Dns-isoleucine was detected. Co-chromatography of 0.1 nmole of these Dns-amino acids gave readily discernable spots.

\section{Amino acid analysis}

Table I shows the results of the amino acid analysis of staphylocoagulase (from ref. 12), and our preparation of prothrombin and coagulase-thrombin. Coagulasethrombin was obtained by mixing equimolar amounts of prothrombin and staphylocoagulase and separating the product by gel filtration on Biogel P-150. The values represent the means of three experiments. We calculated the sum of the amino acid compositions (residues per molecule) of coagulase-thrombin on the assumption that it is formed from one molecule of prothrombin and one molecule staphylocoagulase.

\section{TABLE I}

\section{AMINO ACID COMPOSITION OF STAPHYLOCOAGULASE, PROTHROMBIN AND COAGULASE-THROMBIN}

Column a: $\mathrm{g}$ amino acid/100 g protein; $\mathrm{b}$ : nearest integer to mole amino acid/mole protein; $\mathrm{c}$ : calculated amino acid composition assuming that one molecule of coagulase-thrombin consists of one molecule of prothrombin and one molecule of staphylocoagulase.

\begin{tabular}{|c|c|c|c|c|c|c|c|}
\hline \multirow[t]{2}{*}{ Amino acid } & \multicolumn{2}{|c|}{$\begin{array}{l}\text { staphylocoagulase } \\
\left(M_{\mathrm{r}}=61000\right)\end{array}$} & \multicolumn{2}{|c|}{$\begin{array}{l}\text { Prothrombin } \\
\left(M_{\mathrm{r}}=74000\right)\end{array}$} & \multicolumn{2}{|c|}{$\begin{array}{l}\text { Coagulase-thrombin } \\
\left(M_{\mathrm{r}}=135.000\right)\end{array}$} & \multirow{2}{*}{$\begin{array}{l}\text { Calculated } \\
\text { c }\end{array}$} \\
\hline & a & b & a & $\mathrm{b}$ & a & $\mathrm{b}$ & \\
\hline Lysine & 9.10 & 43 & 4.85 & 28 & 5.54 & 58 & 71 \\
\hline Histidine & 1.89 & 8 & 1.98 & 11 & 2.15 & 21 & 19 \\
\hline Arginine & 4.01 & 16 & 8.18 & 39 & 7.56 & 65 & 55 \\
\hline Aspartic acid & 13.18 & 70 & 9.89 & 64 & 10.99 & 129 & 134 \\
\hline Threonine & 4.74 & 29 & 5.21 & 38 & 5.39 & 73 & 67 \\
\hline Serine & 3.71 & 26 & 4.25 & 36 & 4.68 & 73 & 62 \\
\hline Glutamic acid & 17.58 & 83 & 13.36 & 77 & 13.92 & 145 & 160 \\
\hline Proline & 2.82 & 18 & 4.50 & 34 & 3.83 & 53 & 52 \\
\hline Glycine & 3.38 & 36 & 3.75 & 49 & 4.76 & 113 & 85 \\
\hline Alanine & 5.09 & 44 & 3.61 & 38 & 5.17 & 98 & 82 \\
\hline Cystine & 1.64 & 10 & 3.84 & 28 & 2.58 & 34 & 38 \\
\hline Valine & 6.96 & 43 & 4.53 & 34 & 5.97 & 81 & 77 \\
\hline Methionine & 1.51 & 7 & 1.38 & 8 & 1.52 & 16 & 15 \\
\hline Isoleucine & 6.42 & 35 & 318 & 21 & 4.28 & 51 & 56 \\
\hline Leucine & 7.70 & 42 . & 6.48 & 42 & 6.88 & 82 & 84 \\
\hline Tyrosine & 3.99 & 15 & 4.95 & 22 & 3.72 & 31 & 37. \\
\hline Phenylalanine & 4.53 & 19 & 3.80 & 19 & 3.81 & 35 & 38 \\
\hline Tryptophan & 0.60 & 2 & 3.09 & 12 & 1.83 & 13 & 14 \\
\hline Totals & 98.85 & 546 & 90.83 & 600 & 94.68 & 1171 & 1146 \\
\hline
\end{tabular}

The protein contaminating our staphylocoagulase preparation $(\approx 10 \%)$ and our prothrombin preparation $(<5 \%)$ will probably be separated from the bulk of the material during the preparation of coagulase-thrombin. This introduces an error per se in the sum of the errors in the molecular weight determination $(3-4 \%)$ and in the amino acid determination $(1,25 \%)$.

Antibodies were prepared in rabbits against a coagulase-thrombin preparation. 


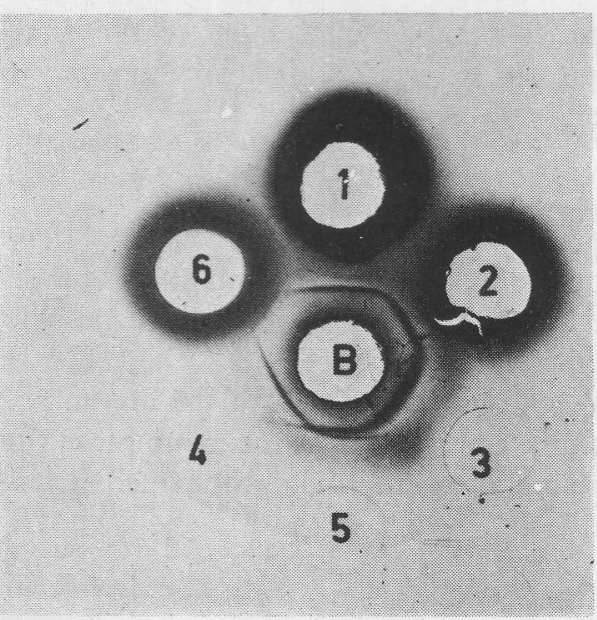

Fig. 6. Double immunodiffusion of an antibody against coagulase-thrombin. The centre well contains the antibody, the other wells contain: 1 . normal plasma; 2. normal serum; 3 . prothrombin; 4. staphylocoagulase; 5 . coagulase-thrombin; 6. thrombin.

These antibodies show single precipitation lines against prothrombin and staphylocoagulase. Against coagulase-thrombin a double line was observed, one continuous with the precipitation line of prothrombin, another continuous with that of staphylocoagulase. Against normal thrombin no precipitation line was found (Fig. 6).

\section{DISCUSSION}

A. The following evidence can be brought forward against the hypothesis that staphylocoagulase forms thrombin by enzymatically splitting prothrombin and in favour of the hypothesis that one molecule of prothrombin interacts with one molecule of staphylocoagulase to form one molecule of coagulase-thrombin.

(1) The kinetics of the generation of coagulase-thrombin is not compatible with the view that staphylocoagulase is an enzyme and prothrombin a substrate (Fig. 1).

2. Staphylocoagulase can be "titrated" with prothrombin to find a point beyond which further addition of prothrombin does not increase the esterase or clotting activity in the mixture (Figs 2 and 3 ).

3. Maximal coagulase-thrombin activity is found when equimolar amounts of prothrombin and staphylocoagulase are added (Fig. 4).

4. The molecular weight of coagulase-thrombin as obtained by gel filtration and sodium dodecylsulphate-polyacrylamide gel electrophoresis is $130000 \pm 5100$ (mean value of both methods). The sum of the molecular weights of prothrombin and staphylocoagulase is $134000 \pm 4900$ (Fig. 5).

5. Coagulase-thrombin has antigenic determinants in common with prothrombin and coagulase-thrombin but not with thrombin (Fig. 6).

6. The amino acid composition of one molecule of coagulase-thrombin within the limits of experimental error equals the sum of the amino acid compositions of 
prothrombin and staphylocoagulase. Unfortunately the experimental error is large as the three types of error add: (a) Up to $7 \%$ contaminating protein may be present in the mixture of prothrombin and staphylocoagulase. This introduces an error as the contaminations will be separated from coagulase-thrombin during the isolation of the latter. To this add: (b) The S.E. of the molecular weight determination, i.e. $\approx 4 \%$. (c) . The S.E. of the amino acid determinations, i.e. $\approx 1.5 \%$.

The mode of interaction between prothrombin and staphylocoagulase is not indicated by these results. It is clear that it cannot be the proteolytic breakdown of prothrombin to thrombin as occurs in physiological blood coagulation [1-5] or by trypsin [17] or by Echis Carinata venom [18]. It is conceivable that proteolysis does play a role but that the products do not or only partly dissociate from the enzyme. The determination of the molecular weight and amino acid composition do not exclude the possibility that a peptide of molecular weight $<14000$ is split off.

B. The following evidence can be brought forward in favour of the hypothesis that the interaction between prothrombin and staphylocoagulase to form coagulasethrombin does not involve splitting of a peptide bond.

1. No small-molecular weight peptide material was detected in the mixtures when coagulase-thrombin had generated.

2. No N-terminal amino acids were found in coagulase-thrombin other than those of prothrombin and staphylocoagulase. So unless a new N-terminal was not detectable by the method used, or was alanine or aspartic acid, no new N-terminals had generated. The $\mathrm{N}$-terminal of thrombin (threonine and isoleucine) were explicitly absent.

Our hypothesis is that prothrombin and staphylocoagulase form a one to one complex in which the tertiary structure of prothrombin is changed so as to form an active centre comparable to that of thrombin. The complex must be fairly stable as no dissociation was observed upon gel filtration or (sodium dodecylsulphate) polyacrylamide-gel electrophoresis. The appearance of two bands upon double immunodiffusion (Fig. 6) is slightly puzzling. This may indicate dissociation of the complex under the conditions of the test, but can be alternatively explained by the assumption of two populations of antibodies, one directed against prothrombin and the prothrombin part of coagulase-thrombin, the other against staphylocoagulase and the staphylocoagulase part of coagulase-thrombin.

\section{REFERENCES}

1 Mann, K. G., Heldebrant, C. M. and Fass, D. N. (1971) J. Biol. Chem. 246, 6106-6114

2 Heldebrant, C. M. and Mann, K. G. (1973) J. Biol. Chem. 248, 3642-3652

3 Owen, W. G., Esmon, C. T. and Jackson, C. M. (1974) J. Biol. Chem. 249, 594-605

4 Jesty, J. and Esnouf, M. P. (1973) Biochem. J. 131, 791-799

5 Magnusson, S. in The Enzymes (Boyer, P. D., ed.), 3rd. edn, Vol. 3, pp. 277-321 Academic Press, London

6 Tager, M. (1948) J. Biol. Med. 20, 487-501

7 Tager, M. (1956) J. Exp. Med. 104, 675-686

8 Drummond, M. C., Tager, M. (1962) J. Bacteriol. 83, 975-980

9 Soulier, J. P., Prou-Wartelle, O. and Hallé, L. (1967) Thromb. Diath. Haemorrh. 17, 321-331

10 Muller, A. D. and Hemker, H. C. (1968) Abstr. 6th FEBS Meet., Madrid, No. 834

11. Devilee, P. P., Hemker, H. C. and Bas, B. M. (1975) Biochim. Biophys. Acta 379, 172-179

12 Bas, B. M., Muller, A. D. and Hemker, H. C. (1975) Biochim. Biophys. Acta 379, 164-171

13 Barton, P. G. (1967) Biochim. Biophys. Acta 133, 506-518 
14 Jackson, C. M., Johnson, T. F. and Hanahan, D. J. (1968) Biochemistry 7, 4492-4505

15 Hemker, H. C., Swart, A. C. W. and Alink, A. J .M. (1972) Thromb. Diath. Haemorrh. XXVII, 205-211

16 Andrews, P. (1964) Biochem. J. 91, 222-233

17 Engel, A. M. and Alexander, B. (1973) Biochim. Biophys. Acta 320, 687-700

18 Schieck, A., Kornalik, F. and Habermann, E. (1969) Naunyn-Schmiedeberg's Arch. Pharmacol. 264,259 